\title{
Another cell death induction system: TNF- $\alpha$ acts as a ligand for fas in vaginal cells
}

\author{
Atsushi Suzuki, ${ }^{*, 1,2}$, Yumi Tsutomi ${ }^{1}$, Motomu Shimizu ${ }^{3}$ and \\ Akio Matsuzawa ${ }^{4}$
}

${ }^{1}$ Daiichi Pharmaceutical Co., Ltd., Drug Safety Research Laboratory, Tokyo R \& D center 16-13, Kitakasai 1, Edogawa-ku, Tokyo 134, Japan

2 Daiichi Pharmaceutical Co., Ltd., Project for the Cell Death Research, Basic Technology Research Laboratory, Tokyo R \& D center 16-13, Kitakasai 1, Edogawa-ku, Tokyo 134, Japan

${ }^{3}$ Tokyo Metropolitan Institute of Medical Science, Department of Cancer Therapeutics, Honkomagome 3-18-22, Bunkyo-ku, Tokyo 134, Japan

${ }^{4}$ University of Tokyo, Laboratory of Animal Research Center, Institute of Medical Science, Shirokanedai, Minato-ku, Tokyo 108, Japan

* corresponding author: Atsushi Suzuki, Daiichi Pharmaceutical Co., Ltd., Project for the Cell Death Research, Basic Technology Research Laboratory, Tokyo R\&D center 16-13, Kitakasai 1, Edogawa-ku, Tokyo 134, Japan. tel: 81-3-5696-9167; fax: 81-3-5696-8336; e-mail: LEB00373@nifty.ne.jp

Received 02.09.98; revised 22.02.99; accepted 14.04.99 Edited by A. Strasser

\begin{abstract}
The death receptor Fas transduces apoptotic death signaling upon stimulation with the Fas ligand. We previously reported that Fas contributes to vaginal cell death observed during the estrus cycle and after estrogen deprivation, using the functional Fas-lacking $I p r$ and $I \mathrm{pr}^{c g}$ mutant mouse. In the present study, we investigated whether the Fas ligand also plays a dominant role in vaginal cell death using the functional Fas ligand-lacking gld mutant mouse. Our results demonstrated that vaginal cells of gld mice do not show any abnormalities, suggesting the possible presence of another ligand for Fas. Through our investigation, we demonstrated TNF- $\alpha$ as a ligand for vaginal Fas. Here, we propose that TNF- $\alpha$ acts for the ligand for Fas in vaginal cells, suggesting a new cell death induction system.
\end{abstract}

Keywords: Fas; TNF- $\alpha$; reproductive tract vagina; apoptosis cell death'1. Apoptotic cell death shows condensation and fragmentation of nuclei, loss of plasma membrane microvilli, condensation of cytoplasm, and fragmentation of chromosomal DNA into 180 bp oligomers. ${ }^{1,2}$ Recently, various deathassociated genes have been identified, some functioning to promote the death signaling and others acting to prevent it.

The death receptor Fas (APO-1/CD95) is a cell surface molecule belonging to the nerve growth factor/tumor necrosis factor (TNF) receptor family and transduces apoptotic death signaling upon stimulation with Fas ligand, a novel member of the TNF family. ${ }^{3}$ Endogenous expression of Fas was found in thymus, lung, liver, ovary and male and female reproductive tracts. ${ }^{4-6} \mathrm{~A}$ dominant role of Fas in physiological cell death and disease states of the thymus and liver has been reported. ${ }^{7-9} L p r$ and $I p r^{g g}$ mutants were identified as endogenous Fas-lacking mice caused by insertion of an early transposable element (ETn) or a point mutation in the death domain. ${ }^{10}$ Using these mutant mice, we demonstrated that Fas plays a dominant role in physiological cell death and disease states of male and female reproductive tracts. ${ }^{5,6,11}$ In addition, the gld mutant mouse was reported as a Fas ligand-lacking mouse, resulting from a point mutation. ${ }^{12}$

Cell proliferation in male and female reproductive tracts is regulated by gonad steroid hormones, especially estrogen and androgen. ${ }^{13}$ Therefore, estrogen- or androgen-deprivation induces cell death in these tissues, accompanying the down-regulation of $\mathrm{Bcl}-2$ oncoprotein. ${ }^{5,6,11,14}$ We previously demonstrated a dominant role of Fas in male and female reproductive tracts, especially vagina, prostate and epididymis, and established these tissues as an in vivo Fas-mediated apoptosis model. ${ }^{5,6}$ In the present study, we examined whether the Fas ligand also plays a dominant role in vaginal cells to further investigate the molecular mechanisms of reproductive cell death. The results demonstrate the presence of another possible ligand for Fas, suggesting cell variation in Fasmediated apoptosis.

\section{Results}

\section{Fas ligand/Fas system in the vagina}

We previously reported that Fas-mediated apoptosis occurred in vaginal cells after estrogen deprivation induced by gonadectomy. ${ }^{5}$ In the present study, vaginae from wild type mice showed regression 2 days after gonadectomy, but those from Ipr mutant mice did not (Figure 1), consistent with our previous observations. ${ }^{5}$ When gld mutant mice were gonadectomized to investigate whether Fas ligand also plays a dominant role in vaginal cell death, those showed estrogen dependency, namely regression after estrogen deprivation (Figure 1) and normal estrus cycle (data not shown). These results indicate that Fas plays a dominant role

Programmed cell death is an indispensable process for cell homeostasis and observed in various physiological phenomena and disease states, with two processes characterized by distinct morphology termed 'apoptotic cell death' and 'necrotic 


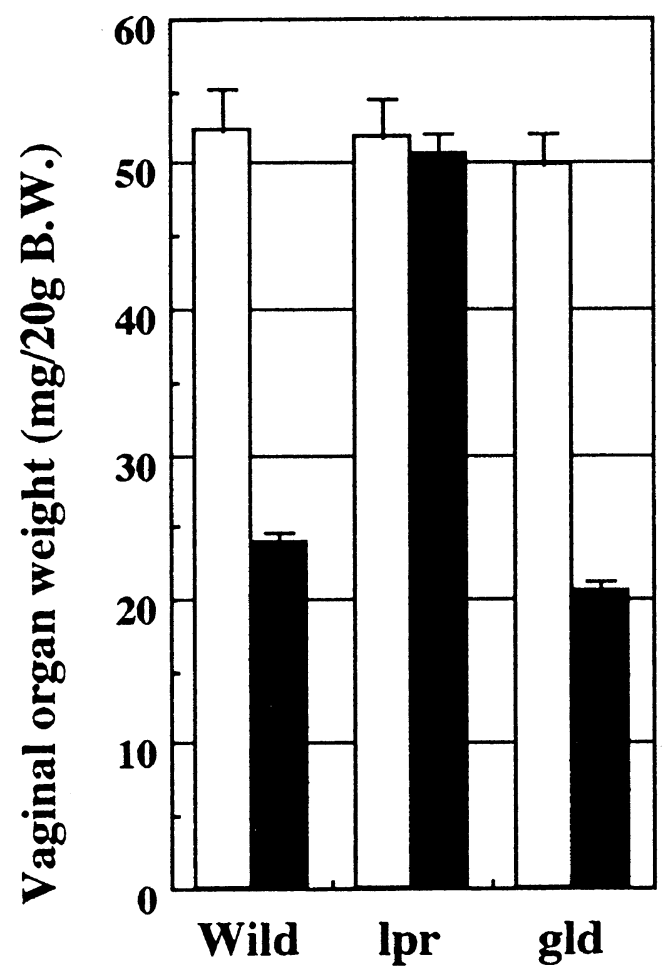

Figure 1 Vaginal regression induced by gonadectomy. Fas-mediated apoptosis in mouse vagina is accompanied by decrease in vaginal organ weight $(5,33)$. Vaginae were weighed from wild type (Wild), Ipr/Ipr (Ipr) and $\mathrm{g} / \mathrm{d} / \mathrm{g} / \mathrm{d}$ (gld) mice before (open) and 2 days after (closed) gonadectomy. Bars are S.E. of vaginal weight. Five mice/group were used for experiments and experiments were repeated five times

in vaginal cell death, but Fas ligand does not, implying the presence of alternate ligands for Fas.

\section{TNF- $\alpha$ /TNF-R1 system in the vagina}

It is known that tumor necrosis factor- $\alpha$ (TNF- $\alpha$ ) belongs to the same family as Fas ligand and transduces apoptotic death signaling through the type-I TNF receptor (TNFR1). ${ }^{3,15}$ Therefore, we examined the possibility that the TNF- $\alpha / T N F-R 1$ death-inducing system may participate in the vaginal Fas-mediated apoptosis. As shown in Figure 2A, TNF- $\alpha$ was newly expressed in vaginal tissues by the estrogen deprivation (2 days after gonadectomy). In contrast, expression of TNF-R1 was not detected before and after gonadectomy (Figure 2B).

\section{Physical interaction between Fas and TNF- $\alpha$}

Our above results led us to the possibility that TNF- $\alpha$ may bind to Fas and induce apoptotic death signaling in vagina. Therefore, we investigated this potential interaction between Fas and TNF- $\alpha$. As shown in Figure 3, murine recombinant TNF or Fas was co-immunoprecipitated by antibodies for Fas or TNF in vaginal cells and murine Fas-expressing hepatoma F6b cells, ${ }^{16}$ but not in N1d cells (control for F6b cells).

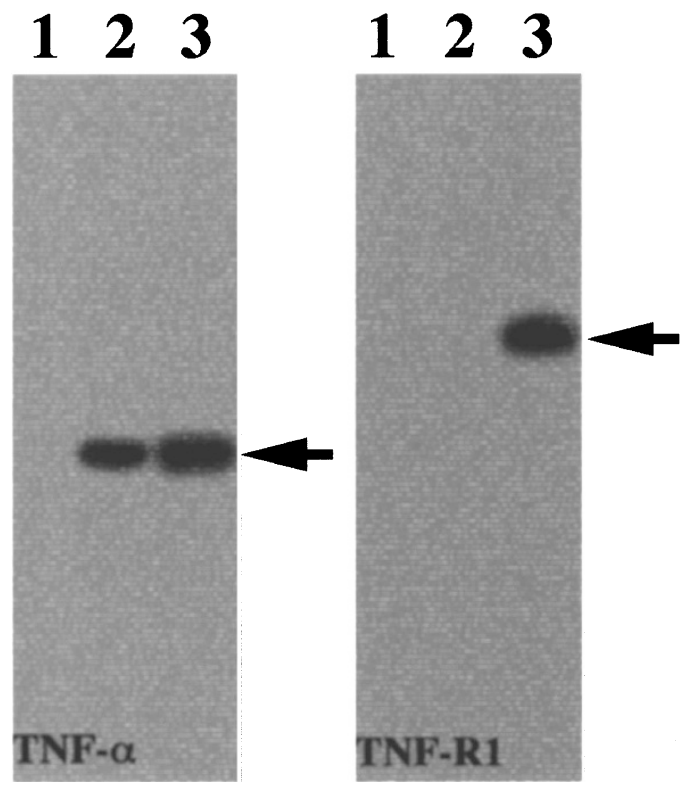

Figure 2 Expression of TNF- $\alpha$ and TNF-R1. Vaginal proteins were extracted from wild type mice before (lane 1) and 2 days after (lane 2) gonadectomy. Immunoblotting with antibodies for TNF- $\alpha$ (left) or TNF-R1 (right) was performed. In the present study, cultured medium (immunoprecipitation) of LPS-treated mouse macrophage RAW264.7 cells (lane 3, left and ${ }^{34}$ ) and cell membrane proteins (immunoblotting) extracted from mouse fibroblast L929 cells (lane 3 , right) were used as the positive control. The arrows show the position of TNF- $\alpha$ (left) or TNF-R1 (right)

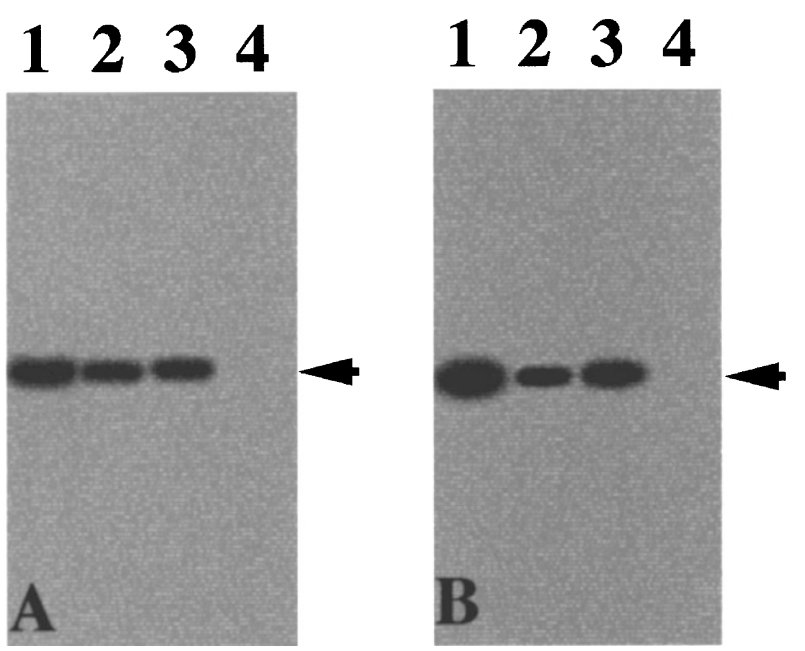

Figure 3 Co-immunoprecipitation analysis of Fas and TNF- $\alpha$. (A) Fas coimmunoprecipitated with TNF- $\alpha$. Cell surface proteins of vaginal cells (lane 2), F6B cells (lane 3 ) and N1d cells (lane 4 ) were labeled with biotin, and reacted with $100 \mathrm{ng}$ mouse recombinant TNF- $\alpha$ for $2 \mathrm{~h}$ on ice. After reaction, cells were lysed with buffer and immunoprecipitated with anti-mouse TNF- $\alpha$ antibody. Immunoprecipitates were dissolved in SDS-containing buffer, heated and separated on $10 \%$ SDS-PAGE. Vaginal Fas which was collected by immunoprecipitation with anti-mouse Fas antibody was used as the positive control for Fas (lane 1). The arrow shows the position of Fas. (B) TNF- $\alpha$ coimmunoprecipitated with Fas. Vaginal cells (lane 2), F6b cells (lane 3) and N1d cells (lane 4) were reacted with $100 \mathrm{ng}$ TNF- $\alpha$, lysed with buffer, and then immunoprecipitated with anti-mouse Fas antibody (Jo2 clone). Immunoprecipitates were separated on $12.5 \%$ SDS-PAGE, and then immunoblotted with anti-mouse TNF- $\alpha$ antibody. Mouse recombinant TNF- $\alpha$ used for the coimmunoprecipitation analysis was included as the positive control (lane 1). The arrow shows the position of TNF- $\alpha$. 


\section{Biological interaction between Fas and TNF- $\alpha$}

We examined whether TNF- $\alpha$ could induce apoptosis through interaction with Fas. Vaginal cells, F6b and N1d cells were treated with agonistic anti-mouse Fas antibody (Jo2 Ab: Jo2 clone and ${ }^{7}$ ) or mouse recombinant TNF- $\alpha$ (TNF). As shown in Figure 4A, Jo2 Ab-induced apoptosis was observed in both F6b and vaginal cells, but TNF induced only in vaginal cells. Vaginal cells from Ipr and gld mutant mice were prepared to further examine TNF-induced apoptosis in vaginal cells. Vaginal cells from an $\mathrm{Ipr}$ mutant mouse did not show apoptosis by either Jo2 Ab or TNF (Figure 4B). In contrast, both Jo2 Ab and TNF induced apoptosis in the gld vaginal cells (Figure 4B).

\section{TNF- $\alpha$ induces apoptosis through Fas in vaginal cells}

Our present results suggested that TNF- $\alpha$ induces apoptosis through Fas in vaginal cells. To directly demonstrate this, we

A

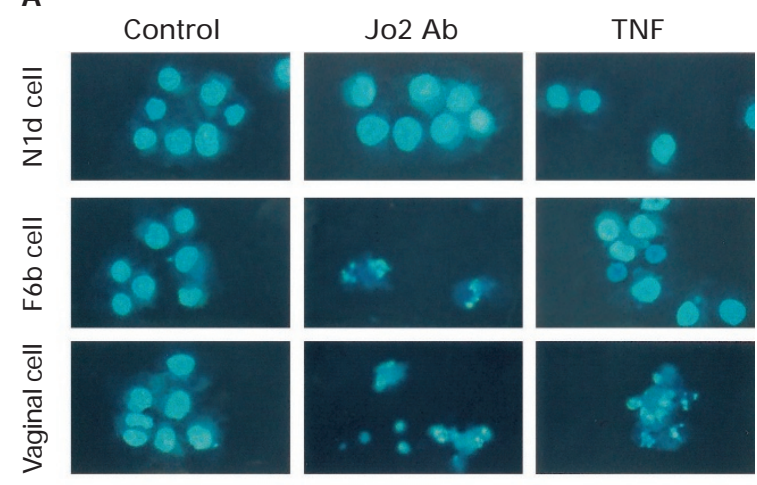

B
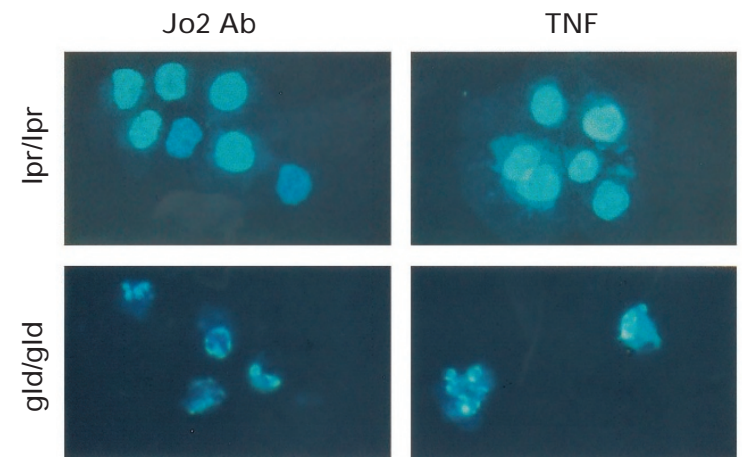

Figure 4 Nuclear morphology of Jo2 antibody- or TNF- $\alpha$-treated cells. (A) F6b, N1d and vaginal cells were treated with or without (Control) $1 \mu \mathrm{g} / \mathrm{ml} \mathrm{Jo2}$ antibody (Jo2 Ab) or $100 \mathrm{ng} / \mathrm{ml}$ mouse recombinant TNF- $\alpha$ (TNF) for $12 \mathrm{~h}$, and then stained with Hoechst 33342. (B) Vaginal cells derived from $/ p r$ or gld mutant mice were treated with $1 \mu \mathrm{g} / \mathrm{ml} \mathrm{Jo2} \mathrm{antibody} \mathrm{(Jo2} \mathrm{Ab)} \mathrm{or} 100 \mathrm{ng} / \mathrm{m}$ mouse recombinant TNF- $\alpha$ (TNF) for $12 \mathrm{~h}$, and then stained with Hoechst 33342 investigated effects of antagonistic Fas and TNF-R1 antibodies in TNF- $\alpha$-induced apoptosis of vaginal cells. When cells were pretreated with antagonistic Fas antibody (C6-1 clone), Jo2 Ab- and TNF-induced apoptosis were not observed (Figure 5). In contrast, antagonistic TNF-R1 antibody did not show any effects in Jo2 Ab- and TNFinduced apoptosis (Figure 5).

\section{Analysis of TNF- $\alpha$ deficient mouse}

Our present results strongly suggest that vaginal cell death is induced by TNF- $\alpha$ through Fas. Therefore, we analyzed the reproductive system of TNF- $\alpha$-deficient mouse ${ }^{17,18}$ to directly demonstrate our hypothesis. The analysis of vaginal smear showed the persistent estrous stage (data not shown), same as $I p r$ or $I p r^{c g}$ mutant mouse. In addition, estrogen deprivation triggered by gonadectomy did not induce a decrease in vaginal organ weight (Figure 6). These results indicate that $\mathrm{TNF}-\alpha$ regulates the vaginal estrous cycle.

\section{Discussion}

The death receptor Fas transduces apoptotic death signaling upon stimulation with Fas ligand or agonistic Fas antibody. ${ }^{3}$ The physiological role of Fas in the immune system and various disease states, like hepatitis has been well investigated, ${ }^{3}$ however, that in other tissues has not been elucidated. Recently, we demonstrated that Fas regulated the vaginal apoptosis observed during the estrus cycle and after

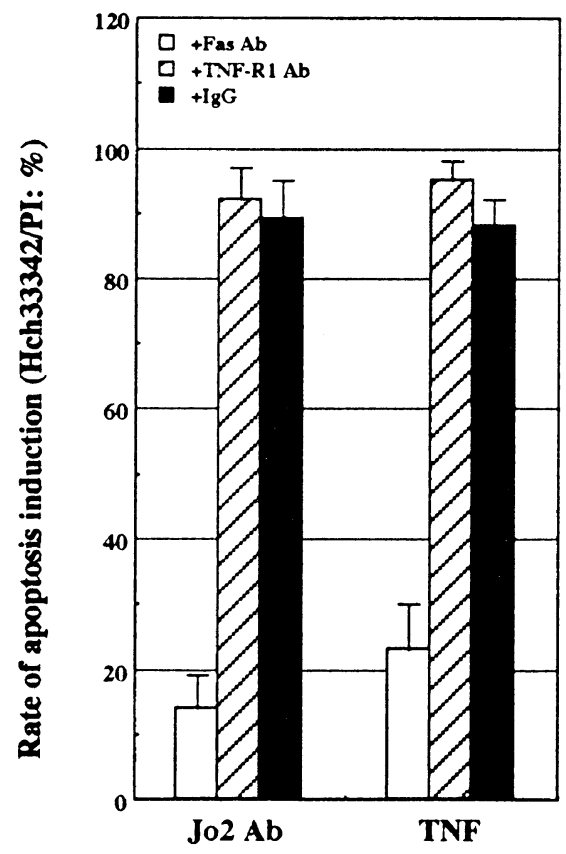

Figure 5 Effect of antagonistic antibody in Fas Ab- and TNF-induced apoptosis. Vaginal cells were pretreated with $1 \mu \mathrm{g} / \mathrm{ml}$ antagonistic antibody for Fas or TNF-R 1 for $2 \mathrm{~h}$, and then Jo2 Ab $(1 \mu \mathrm{g} / \mathrm{ml})$ or mouse recombinant TNF- $\alpha$ $(10 \mathrm{ng} / \mathrm{ml})$ treatment was performed for $12 \mathrm{~h}$. After treatment, cells were stained with Hoechst 33342 , and the extent of apoptosis induction was measured as the ratio of apoptotic nuclei in total nuclei (about 5000 cells) 


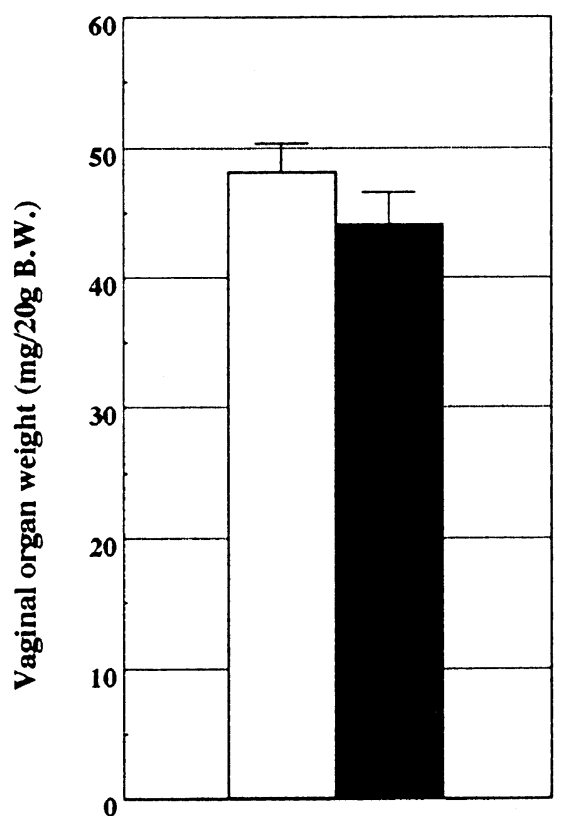

Figure 6 Analysis of TNF- $\alpha$ deficient mouse. Vaginae were weighed from TNF- $\alpha$ deficient mouse before (open) and 2 days after (closed) gonadectomy. Bars are S.E. of vaginal weight. Five mice/group were used for experiments

estrogen deprivation induced by gonadectomy. ${ }^{5}$ In addition, the functional absence of Fas induced by neonatal exposure of synthesized estrogen diethylstilbestrol (DES) initiated the persistent proliferation of vaginal epithelia, namely the DES syndrome. ${ }^{11,13,19}$ Thus, Fas plays a dominant role in the vagina, and we investigated whether Fas ligand also participates in apoptosis of vaginal cells.

When intact mice were gonadectomized, vaginal regression accompanied by a decrease in vaginal organ weight occurred. In contrast, the functional Fas-lacking Ipr/ Ipr mutant mice ${ }^{10}$ did not show this, consistent with our previous report. ${ }^{5}$ However, the functional Fas ligand-lacking gld/gld mice showed the vaginal regression after gonadectomy. These results indicate that Fas ligand did not participate in vaginal apoptosis, implying the presence of another ligand for Fas in vaginal cells.

The Fas ligand belongs to the same family as tumor necrosis factor (TNF)- $\alpha$ which also is a death inducing factor. $^{20}$ We examined whether TNF- $\alpha$ was expressed during vaginal Fas-mediated apoptosis, and found specific expression of TNF- $\alpha$. In general, TNF- $\alpha$ induces apoptotic death signaling through the type-1 TNF receptor (TNF-R1) in various cells. ${ }^{15}$ However, TNF-R1 expression was not observed during vaginal Fas-mediated apoptosis. These results led us to one possibility that TNF- $\alpha$ may interact with Fas to induce apoptosis in vaginal cells.

We prepared two kinds of cells, endogenous Fasexpressing vaginal cells and exogenous Fas-expressing (mouse Fas cDNA-transfected) $\mathrm{F} 6 \mathrm{~b}$ cell, ${ }^{16}$ to investigate the interaction between Fas and TNF- $\alpha$. Our present results demonstrated that mouse recombinant TNF- $\alpha$ could bind to both endogenous and exogenous Fas. However, a biological interaction, namely apoptosis induction, was observed in only the vaginal cells. TNF- $\alpha$ could bind to Fas, but induction of apoptotic cell death was cell-type specific. Recently, the Fas-DISC (Fas-death inducing signaling complex) was reported as an essential factor(s) which directly interacts with the Fas-death domain. ${ }^{21,22}$ FADD and caspase 8 (FLICE/MACH) was also identified as the Fas-DISC. ${ }^{23-25}$ We did not observe any differences in expression of FADD or caspase 8 between vaginal cells and F6b cells, but some proteins which were unknown and were not detected in Fas-DISC from F6b cells, were extracted as the vaginal Fas-DISC (data not shown). The different sensitivity to TNF- $\alpha$ in Fas-expressing cells may be due to the differences in the Fas-DISC pattern. We additionally suggest that different sensitivity to TNF- $\alpha$ in Fas-expressing cells causes the cell variation of Fasmediated apoptosis. Previous evidences about an interaction between TNF- $\alpha$ and Fas has been reported by Leithauser et $a l,{ }^{26}$ and TNF- $\alpha$ up-regulates Fas expression similar to interferon- $\gamma^{4}$ In the present study, we demonstrated a direct association between Fas and TNF- $\alpha$, namely binding and apoptosis induction, using vaginal cell.

Our present results strongly suggested that TNF- $\alpha$ acts as a ligand for Fas in the vaginal cell. To further demonstrate this, we investigated effects of antagonistic antibodies for Fas and TNF-R1. In the present study, TNFR1 expression was not detected in vaginal cells. In addition, TNF- $\alpha$ could induce apoptosis in vaginal cells even in the presence of antagonistic TNF-R1 antibody. These results indicate that TNF- $\alpha$ can induce apoptosis independent of TNF-R1. In contrast, apoptosis induction was suppressed when cells were masked with antagonistic Fas antibody. On the basis of our present results, therefore, we suggest that TNF- $\alpha$ can induce apoptosis through Fas in vaginal cells.

Vaginal cell death and proliferation observed during an estrous cycle are regulated by ovarian steroid estrogen. Especially, vaginal cell death is transduced by Fas. ${ }^{5}$ So, mice lacking functional Fas show the persistent proliferation of vaginal epithelia. ${ }^{5}$ Thus, vaginal cell death is initiated by Fas, but its stimulation is not triggered by Fas ligand. Our present results strongly suggest that TNF- $\alpha$ induces vaginal cell death through Fas. And, analysis of TNF- $\alpha$-deficient mice strongly supported this hypothesis. Expression of TNF-R1 was not observed in vaginal cells, however, TNF- $\alpha$ deficient mice showed the persistent estrous stage and the resistance to estrogen regulation. We demonstrated two important evidences. (1) Fas is an essential factor for the vaginal cell death, but Fas ligand is not. (2) TNF- $\alpha$ is necessity for the vaginal cell death, but TNF-R1 is not expressed in vaginal cells. On the basis of these evidences, we hypothesize that vaginal cell death is initiated by new death induction machinery, TNF- $\alpha /$ Fas system.

We have established the mouse vaginal cell as an in vivo model of Fas-mediated apoptosis, ${ }^{5}$ and we continued the characterization of our model in the present study. Fas regulates the vaginal cell death observed during the estrus cycle and after estrogen deprivation, but its death signaling is not initiated by Fas ligand. We demonstrated TNF- $\alpha$ as a 
ligand for Fas in vaginal cell. TNF- $\alpha$ can bind to Fas in various types of cells, but death induction is initiated only in limited cell types, such as the vaginal cell. We could not clarify the molecular mechanism of this selective death induction in the present study. However, we detected some unknown Fas-DISC in the vaginal cell which may contribute to this selective death induction. We have also reported that mouse male reproductive tracts, prostate and epididymis, and pregnancy-dependent mammary tumor (PDMT) showed apoptotic regression after androgen deprivation or parturition. ${ }^{6,27}$ During these apoptosis, Fas also plays a dominant role, but Fas ligand does not ( $A$. Suzuki, unpublished data). Therefore, our present findings of novel death induction by a TNF- $\alpha /$ Fas system, is not specific for vaginal cells, but also operates in the limited case. Further studies will be needed to clarify the molecular mechanism of selective death induction by the TNF- $\alpha$ through Fas and the localization where TNF- $\alpha / F$ as system can operate to induce tissue regression.

\section{Materials and Methods}

\section{Animals}

Female C57BL/Tw, Ipr/lpr mutant $\mathrm{C} 3 \mathrm{H}$ and gld/gld mutant CBA mice were kept in a $12 \mathrm{~h}$ light $/ 12 \mathrm{~h}$ dark environment at $23-25^{\circ} \mathrm{C}$ and given standard laboratory chow (CE-2, CLEA, Tokyo, Japan) and tap water ad libitum. Two-month-old female mice at estrus stage were gonadectomized and sacrificed. In the present study, five mice in each group were used, and each experimental procedure was performed three times.

\section{Protein extraction}

Proteins from each tissue were prepared for immunoblotting analysis by a method described previously. ${ }^{28}$ Tissues were vortexed without homogenization in $8 \mathrm{M}$ urea containing $1 \%$ SDS and $2.5 \%$ dithiothreitol (DTT, Sigma, St. Louis, MO, USA), then vortexed again after the addition of $10 \%$ NP-40. The extracts were obtained by centrifugation at 15000 r.p.m. All procedures were carried out at $4^{\circ} \mathrm{C}$. Protein concentrations in the supernatant were determined by the method described previously ${ }^{29,30}$ using BCA protein assay reagent (Pierce, Rockford, IL, USA) with bovine serum albumin as a standard.

\section{Immunoblotting analysis}

Expression of TNF- $\alpha$ and TNF-R1 was examined using an immunoblotting approach. Sample proteins separated by SDSPAGE were transferred onto nitrocellulose filters with a semi-dry blotting system. The blotted filters were blocked with PBS containing $5 \%$ (w/v) skim milk (Snow Brand, Sapporo, Japan) at room temperature for $1 \mathrm{~h}$, washed with a mixture of PBS and $0.05 \%$ Tween 20 (Tween-PBS), and then incubated overnight at room temperature with antibodies for TNF- $\alpha$ or TNF-R1 diluted 1:250 with PBS. After washing with Tween-PBS, the filters were incubated with a 1:1000 dilution of biotinylated anti-rat IgG antibody (Vector Lab., Burlingame, CA, USA), washed with Tween-PBS, and then incubated with avidinalkaline phosphatase (avidin-HRP; Vector Lab.) at room temperature for $1 \mathrm{~h}$. Color development procedure was performed using the $\mathrm{ECL}$ system.

\section{Immunoprecipitation analysis}

Mouse Fas was collected with an immunoprecipitation procedure as previously described. $^{5-7,11}$ Cell surface proteins were labeled with biotin (Pierce), lysed in buffer containing NP-40, precleared with normal hamster $\operatorname{lgG}$ and immunoprecipitated with the Jo2 anti-mouse Fas antibody. ${ }^{7}$ The immunoprecipitates were boiled in SDS sample buffer, separated on $10 \%$ polyacrylamide gels, transferred onto nitrocellulose membranes, and incubated with avidin-HRP (Vector Lab.), at room temperature for $45 \mathrm{~min}$.

\section{Co-immunoprecipitation analysis}

Vaginal cells or a mouse hepatoma cell line transfected with mouse Fas cDNA, ${ }^{4} \mathrm{~F} 6 \mathrm{~b}\left(\mathrm{mFas}^{+}\right)$and $\mathrm{N} 1 \mathrm{~d}\left(\mathrm{mFas}^{-}\right)$cells, ${ }^{16}$ were incubated with $1 \mu \mathrm{g} / \mathrm{ml} \mathrm{TNF}-\alpha$ for $1 \mathrm{~h}$ at $4^{\circ} \mathrm{C}$, and then lysed in buffer containing NP-40. After lysis, immunoprecipitation using Jo2 antibody was performed. In separate experiments, cell surface proteins of both cells were biotinylated, and then incubated with $1 \mu \mathrm{g} / \mathrm{ml} \mathrm{TNF}-\alpha$. After lysis, immunoprecipitation using anti-mouse TNF- $\alpha$ antibody was performed. Immunoprecipitates were separated by SDS-PAGE, and immunoblotted with anti-mouse TNF- $\alpha$ antibody (Genzyme), or the detection of biotinylated proteins were performed.

\section{Nuclear morphology analysis}

Nuclear morphology after Jo2 antibody- or TNF- $\alpha$-treatment in F6b, N1d or each vaginal cells was observed with Hoechst 33342/PI staining (Molecular Probes, Inc., Eugene, OR, USA) using a previously described method. ${ }^{31,32}$

\section{Vaginal cell preparation}

Wild type, Ipr/lpr and $\mathrm{g} / \mathrm{d} / \mathrm{g} / \mathrm{d}$ mouse vaginae were removed to prepare vaginal cells. Vaginal epithelial cells were collected with collagenase treatment and incubated in $0.25 \%$ trypsin. Cells were seeded into cell culture dishes or plates, and $1 \times 10^{7}$ (for the co-immunoprecipitation analysis) or $1 \times 10^{4}$ (for the nuclear morphology analysis) cells were used for each experiment.

\section{Acknowledgements}

We thank Drs. Yoshihide Tsujimoto, Osaka University of Medical School, Masayuki Miura, Osaka University of Medical School, and Mitsuru Furusawa, Daiichi Pharmaceutical Co., Ltd., for their valuable discussions, Dr. Kenji Sekikawa, National Institute of Animal Health, for TNF-a deficient mouse, Dr. Shin Yonehara, Kyoto University, for his kind gift of C6-1 clone antibody, and Dr. Hubert Hug, Heidelberg University, for his kind support and valuable discussion.

\section{References}

1. Wyllie AH, Kerr JFR and Currie AR (1980) Cell death: The significance of apoptosis. Int. Rev. Cytol. 68: 251-306

2. Fesus $L$ (1993) Biochemical events in naturally occuring forms of cell death. FEBS lett 328: 1-5

3. Nagata $S$ and Golstein $P$ (1995) The Fas death factor. Science 267: 1449-1456

4. Watanabe-Fukunaga $\mathrm{R}$, Brannan $\mathrm{Cl}$, Itoh N, Yonehara S, Copeland NC, Jenkins NA and Nagata S (1992) The cDNA structure, expression, and chromosomal assignment of the mouse Fas antigen. J. Immunol. 148: 1274-1279

5. Suzuki A, Enari M, Eguchi Y, Matsuzawa A, Nagata S, Tsujimoto $Y$ and Iguchi $T$ (1996) Involvement of Fas in regression of vaginal epithelia after ovariectomy and during an estrous cycle. EMBO J. 15: 211-215 
6. Suzuki A, Matsuzawa A and Iguchi T (1996) Down regulation of Bcl-2 is the first step on Fas-mediated apoptosis of male reproductive tracts. Oncogene 13:3137

7. Ogasawara J, Watanabe-Fukunaga R, Adachi M, Matsuzawa A, Kasugai T, Kitamura Y, Itoh N, Suda T and Nagata S (1993) Lethal effect of the anti-Fas antibody in mice. Nature 364: 806-809

8. Ogasawara J, Suda T and Nagata S (1995) Selective apoptosis of CD4+CD8+ thymocytes by the anti-Fas antibody. J. Exp. Med. 181: 485-491

9. Suzuki A (1998) The dominant role of CPP32 subfamily in Fas-mediated hepatitis. Pro. Soc. Exp. Biol. Med. 217: 450-454

10. Watanabe-Fukunaga R, Brannan Cl, Copeland NG, Jenkins NA and Nagata S (1992) Lymphoproliferation disorder in mice explained by defects in Fas antigen that mediates apoptosis. Nature 356: 314-317

11. Suzuki A, Enari M and Iguchi T (1996) Effect of neonatal exposure to DES on Fas and $\mathrm{Bcl}-2$ expression in the adult mouse vagina: an approach to the DES syndrome. Repro. Toxicol. 10: 465-470

12. Takahashi T, Tanaka M, Brannan Cl, Jenkins NA, Copeland NG, Suda T and Nagata S (1994) Generalized lymphoproliferative disease in mice, caused by a point mutation in the Fas Ligand. Cell 76: 969-976

13. Iguchi $T$ (1992) Cellular effects of early exposure to sex hormones and antihormones. Int. Rev. Cytol. 139: 1-57

14. Tsujimoto Y, Yunis J, Nowell PC and Croce CM (1984) Cloning of the chromosomal breakpoint of neoplastic $B$ cells with the $t(14 ; 18)$ chromosome translocation. Science 226: 1097-1099

15. Old LJ (1985) Tumor necrosis factor (TNF). Science 230: 630-632

16. Shimizu M, Yoshimoto T, Nagata S and Matsuzawa A (1996) A trial to kill tumor cells through Fas (CD95)-mediated apoptosis in vivo. Biochem. Biophys. Res. Commun. 228: $375-379$

17 Taniguchi T, Takata M, Ikeda A, Momotani E and Sekikawa K (1997) Failure of germinal center formation and impairment of response to endotoxin in tumor necrosis factor $\alpha$-deficient mice. Lab. Invest. 77: 647-658

18. Suto J, Matsuura S, Imamura K, Yamanaka Hand Sekikawa K(1998) Genetics of obesity in $\mathrm{KK}$ mouse and effects of Ay allele on quantitative regulation. Mamm. Genome 9: $506-510$

19. Takasugi N, Bern HA and DeOme KB (1962) Persistent vaginal cornification in mice. Science 138: 438

20. Suda T, Takahashi T, Golstein P and Nagata S (1993) Molecular cloning and expression of the Fas ligand, a novel member of the tumor necrosis factor family. Cell 75: $1169-1178$

21. Itoh N, Yonehara S, Ishii A, Yonehara M, Mizushima S, Sameshima M, Hase A Seto Y and Nagata S (1991) The polypeptide encoded by the cDNA for humancell surface antigen Fas can mediate apoptosis. Cell 66: 233-243
22. Kischkel FC, Hellbardt S, Behrmann I, Germer M, Pawlita M, Krammer PH and Peter ME (1995) Cytotoxicity-dependent APO-1 (Fas/CD95)-associated proteins form a death-inducing signaling complex (DISC) with the receptor. EMBO J. 14: $5579-5588$

23. Chinnaiyan AM, O'Rourke K, Tewari M and Dixit VM (1995) FADD, a novel death domain-containing protein, interacts with the death domain of Fas and initiates apoptosis. Cell 81: 505-512

24. Boldin MP, Goncharov TM, Golstev YV and Wallach D (1996) Involvement of $\mathrm{MACH}$, a novel MORT-1/FADD-interacting protease, in Fas/APO-1 and TNF receptor-induced cell death. Cell 85: 803-815

25. Muzio M, Chinnaiyan AM, Kischkel FC, O'Rourke K, Shevchenko A, Ni J, Scaffidi C, Bretz JD, Zhang M, Gentz R, Mann M, Krammer PH, Peter ME and Dixit VM (1996) FLICE, a novel FADD-homologous ICE/CED-3-like protease, is recruited to the CD95 (Fas/APO-1) death-inducing signaling complex. Cell 85: 817-827

26. Leithauser F, Dhein J, Mechtersheimer G, Koretz K, Bruderlein S, Henne C Schmidt A, Debatin K-M, Kramer PH and Moller P (1993) Constitutive and induced expression of APO-1, a new member of the nerve growth factor/tumor necrosis factor receptor superfamily, in normal and neoplastic cells. Lab. Invest. 69: $415-429$

27. Suzuki A, Goto Y and Iguchi T (1997) Progression of PDMT is accompanied by lack of Fas and intense expression of Bcl-2 and PKC- $\varepsilon$. Carcinogenesis 18:883887

28. Wilson DL, Hall ME, Stone GC and Rubin RW (1977) Some improvements in twodimensional gel electrophoresis of proteins. Anal. Biochem. 83: 33-34

29. Smith PK, Krohn RI, Hermanson GT, Mallia AK, Gartner FH, Provenzano MD, Fujimoto EK, Goeke NM, Olson BJ and Klenk DC (1985) Measurement of protein using bicinchoninic acid. Anal. Biochem. 170: 203-208

30. Hill HD and Sraka J (1988) Protein determination using bicinchoninic acid in the presence of sulfhydryl regents. Anal. Biochem. 170: 203-208

31. Hasegawa J, Kamada S, Kamiike W, Shimizu S, Imazu T, Matsuda H and Tsujimoto $Y$ (1996) Involvement of CPP32/Yama(-like) proteases in Fasmediated apoptosis. Cancer Res. 56: 1713-1718

32. Suzuki A, Iwasaki M and Wagai N (1997) Involvement of cytoplasmic serineproteinase and CPP32 subfamily in the molecular machinery of caspase 3 activation during Fas-mediated apoptosis. Exp. Cell. Res. 233: 48-55

33. Suzuki A, Enari M, Abe Y, Ohta Y and Iguchi T (1996) Effect of ovariectomy on histological change and protein expression in female reproductive tracts. In Vivo 10: $103-110$

34. Jeong SY, Lee JH, Kim HS, Hong SH, Cheong CH and Kim IK (1996) 3 Deazaadenosine analogues inhibit the production of tumor necrosis factor- $\alpha$ in RAW264.7 cells stimulated with lipopolysaccharides. Immunology 89: 558-562 